\title{
Case-law of EU Courts on the Right to an Effective Judicial Review
}

Haltern has remarked that, since there was no Treaty basis for the CJEU's initial human rights jurisprudence, the CJEU had "invented, out of thin air, unwritten European human rights". ${ }^{1}$ Rosas describes five stages in the development of human rights protection in the EU: (1) outside the competence of the CJEU; (2) as part of general principles of Community law since 1969; (3) explicit reference to the ECHR since 1974-1979; (4) characterization of the ECHR as having "special significance" since 1989; and (5) reference to individual judgements of the ECtHR since the mid 199 os. ${ }^{2}$ The activism that the EU Courts are accused of originates very often from cases concerning human rights. ${ }^{3}$ As Muir has noted, "if one defines judicial activism as judicial decisions going beyond the legal framework created by political institutions, the Court's traditional case-law on fundamental rights is a prime of judicial activism. It is indeed largely accepted that the Court asserted the constitutional importance of fundamental rights in the EU legal order despite the original will of the Treaty makers". ${ }^{4}$ Interestingly, despite the activism shown by EU courts in cases concerning human rights protection, they have pursued judicial restraint in EU competition law cases, including in relation to fair trial issues raised in competition law disputes. This contradiction is analysed in this chapter.

The entry into force of the EU Charter of Fundamental Rights has marked a new stage in the development of fundamental rights in the EU because, pursuant to the first subparagraph of Article 6(1) TEU, the Charter has the same legal value as the Treaties. In addition, the right to a fair trial has been

1 Haltern, U. "Integration Through Law." European Integration Theory. Eds. A. Weiner and T. Diez. Oxford: Oxford University Press, 2004, p. 183.

2 Rosas, Allan. "With a Little Help from My Friends: International Case-Law as a Source of Reference for the EU Courts." The Global Community Yearbook of International Law and Jurisprudence (2005), pp. 203-230, p. 214.

3 De Búrca, Gráinne. "The Evolution of EU Human Rights Law." The Evolution of EU Law. Eds. Paul Craig and Gráinne de Búrca. Oxford: Oxford University Press, 2011.

4 Muir, Elise. “The Court of Justice: a Fundamental Rights Institution Among Others.” Judicial Activism at the European Court of Justice. Eds. Mark Dawson, Bruno De Witte and Elise Muir. Cheltenham: Edward Elgar, 2013, pp. 76-77. 
formalised for the first time. Thus, Article 47(1) of the Charter provides that everyone whose rights and freedoms guaranteed by EU law are violated has the right to an effective remedy before a tribunal in compliance with the conditions laid down in this article. Article 47(2) stipulates that everyone is entitled to a fair and public hearing within a reasonable time by an independent and impartial tribunal previously established by law. Everyone is to have the possibility of being advised, defended and represented. Lastly, Article 47(3) provides that legal aid is to be made available to those who lack sufficient resources insofar as such aid is necessary to ensure effective access to justice.

According to the explanations relating to Article 47, which, in accordance with the third subparagraph of Article 6(1) TEU and Article 52(7) of the Charter, have to be taken into consideration for the interpretation of the Charter, the second paragraph of Article 47 of the Charter corresponds to Article 6(1) of the ECHR. ${ }^{5}$

The first sentence of Article 52(3) TEU states that, insofar as the Charter contains rights which correspond to those guaranteed by the ECHR, their meaning and scope are to be the same as those laid down by the ECHR. According to the explanation of that provision, the meaning and the scope of the guaranteed rights are to be determined not only by reference to the text of the ECHR, but also, inter alia, by reference to the case-law of the ECHR. The second sentence of Article 52(3) of the Charter provides that the first sentence is not to preclude the grant of wider protection by EU law.

These provisions of the Charter and of the TEU suggest that fundamental rights in the EU should be interpreted at least as widely as the interpretation offered by the ECtHR. ${ }^{6}$ In order to analyse if these Treaty provisions are respected in relation to the review of EU Commission's decisions in competition law cases, the following section will describe the case-law of the EU Courts on the right to effective judicial protection and the right to effective judicial review. As it will be shown, the existing system of judicial review combines limited review of the substance of the case with the unlimited review of fines. The EU Commission's discretion is wide and exercised during all stages of enforcement proceedings. Lastly, this section highlights the connection that the EU Courts have developed between the right to a fair trial and judicial review.

5 Explanations relating to the Charter of Fundamental Rights, quoted above, p. 29.

6 See section 2.5. of this work. 


\subsection{Right to Effective Judicial Protection}

The ECJ recognized relatively early that the principle of effective judicial protection is a general principle of EU law stemming from the constitutional traditions common to the Member States, which has been enshrined in Articles 6 and 13 ECHR. ${ }^{7}$ In Marguerite Johnston, a case which concerned the principle of equal treatment between men and women, the ECJ found that "as the European Parliament, Council and Commission recognized (...) and as the Court has recognized in its decisions, the principles on which that Convention is based must be taken into consideration in Community law". 8 The ECJ also found that "all persons have the right to obtain an effective remedy in a competent court against measures which they consider to be contrary to the principle of equal treatment for men and women" and that it was "for the Member States to ensure effective judicial control as regards compliance with the applicable provisions of Community law and of national legislation intended to give effect to the rights for which the directive provides". 9

In Heylens, the ECJ was faced with a preliminary question seeking to establish whether the principle of the free movement of workers required that it must be possible for a decision refusing to recognize the equivalence of a diploma be made the subject of judicial proceedings. ${ }^{10}$

The ECJ answered affirmatively and found that

effective judicial review, which must be able to cover the legality of the reasons for the contested decision, presupposes in general that the court to which the matter is referred may require the competent authority to notify its reasons. But where, as in this case, it is more particularly a question of securing the effective protection of a fundamental right

7 C-222/84,Johnstonv Chief Constable of the Royal Ulster Constabulary, ECLI:EU:C:1986:206, paragraphs 18 and 19 .

C-222/86, Unectef $v$ Heylens, ECLI:EU:C:1987:442, paragraph 14.

C-424/99, Commission v Austria, ECLI:EU:C:2001:642, paragraph 45.

C-5o/oo P, Unión de Pequeños Agricultoresv Council, ECLI:EU:C:2002:462, paragraph 39.

C-467/o1, Eribrand, ECLI:Eu:C:2003:364, paragraph 61.

8 C-222/84, Johnstonv Chief Constable of the Royal Ulster Constabulary, quoted above, paragraphs 18-19.

9 C-222/84, Johnston $v$ Chief Constable of the Royal Ulster Constabulary, quoted above, paragraph 19 .

$10 \quad \mathrm{C}-222 / 86$, Unectef $v$ Heylens, quoted above. 
conferred by the Treaty on Community workers, the latter must also be able to defend that right under the best possible conditions and have the possibility of deciding, with a full knowledge of the relevant facts, whether there is any point in their applying to the courts. Consequently, in such circumstances the competent national authority is under a duty to inform them of the reasons on which its refusal is based, either in the decision itself or in a subsequent communication made at their request. ${ }^{11}$

Thus, similar to the case-law of the ECtHR, effective judicial protection was not construed by the ECJ as an abstract concept. Rather, the effectiveness required of judicial protection stems from the need to secure the rights conferred by the EU Treaties. Also, effective judicial protection in the EU implies duties both for the domestic competent administrative and judicial authorities.

Starting with Oleificio Borelli, the EU Courts have used a linear analysis for the interpretation of the principle of judicial protection. There, the ECJ has found that judicial control reflects a general principle of Community law stemming from the constitutional traditions common to the member states and enshrined in Articles 6 and 13 ECHR. ${ }^{12}$

In the recent years, the CJEU has developed its jurisprudence on the right to effective judicial protection. However, although the right to an effective legal remedy constitutes a general principle of EU law and was reaffirmed by the Charter, it can only be enforced when the subject-matter of the dispute in the main proceedings is connected with the EU law. In Chartry, the Court noted that a dispute between a Belgian national and the Belgian State concerning taxation of activities carried out within the territory of that Member State, was not connected in any way with the provisions of the EC Treaty on the free movement of persons, of services, or of capital. ${ }^{13}$ Moreover, that dispute did not concern the application of national measures by which that Member State implement EU law. ${ }^{14}$

In the case $D E B$, the CJEU was asked whether the right to effective judicial protection entails legal aid for legal persons in the form of dispensation from payment of the costs of proceedings or from provision of security for costs before an action is brought. ${ }^{15}$ The CJEU highlighted that "the assessment of the

$11 \mathrm{C}-222 / 86$, Unectef $v$ Heylens, quoted above.

12 C-97/91, Oleificio Borelli v Commission, ECLI:EU:C:1992:491.

13 C-457/og, Claude Chartryv Belgian State, ECLI:Eu:C:2011:101.

14 C-457/og, Claude Chartry v Belgian State, quoted above, paragraphs 22-26.

$15 \mathrm{C}-279 / 09, D E B$, quoted above. 
need to grant that aid must be made on the basis of the right of the actual person whose rights and freedoms as guaranteed by EU law have been violated, rather than on the basis of the public interest of society, even if that interest may be one of the criteria for assessing the need for the aid". ${ }^{16}$ The Court showed that the principle of effective judicial protection may cover, inter alia, dispensation from advance payment of the costs of proceedings and/or the assistance of a lawyer. ${ }^{17}$

In Brahim Samba Diouf, the CJEU received a preliminary question asking whether the right to an effective remedy against decisions taken on applications for asylum, and, more generally, the general principle of the right to an effective remedy, must be interpreted as meaning that they preclude rules as a result of which no separate judicial remedy exists against the decision of the competent national authority to examine an application for asylum under an accelerated procedure. ${ }^{18}$

The Court recalled that the effectiveness of a remedy depends on the administrative and judicial system of each Member State seen as a whole and that the principle of judicial protection affords an individual a right of access to a court or tribunal, but not to a number of levels of jurisdiction. ${ }^{19}$

On the facts of the case, the CJEU noted that the procedure to be applied for the examination of the application for asylum, viewed separately and independently from the final decision which grants or rejects the application for asylum, is a measure preparatory to the final decision. As such, an absence of a remedy does not constitute a breach of the right to an effective remedy, "provided, however, that the legality of the final decision adopted in an accelerated procedure - and, in particular, the reasons which led the competent authority to reject the application for asylum as unfounded - may be the subject of a thorough review by the national court, within the framework of an action against the decision rejecting the application".20

16 C-279/og, $D E B$, quoted above, paragraph 42.

$17 \mathrm{C}-279 / 09, D E B$, quoted above, paragraphs 59-62.

18 C-69/10, Brahim Samba Diouf v Ministre du Travail, de l'Emploi et de l'Immigration, ECLI:EU:C:2011:524.

19 C-69/10, Brahim Samba Dioufv Ministre du Travail, de l'Emploi et de l'Immigration, quoted above, paragraphs 46 and 69 .

20 C-69/10, Brahim Samba Dioufv Ministre du Travail, de l'Emploi et de l'Immigration, paragraph 69 . 


\section{Right to Judicial Review in Competition Law Cases - A Matter of Constitutional Design}

Judicial review in EU competition law cases is first of all a matter of constitutional design because its tenets are laid down in the TFEU and Regulation 1/2003. Thus, Article 263 TFEU provides that the CJEU has jurisdiction over actions brought against the Commission's decisions.

More precisely, Article 263 TFEU states that

The Court of Justice of the European Union shall review the legality of legislative acts, of acts of the Council, of the Commission and of the European Central Bank, other than recommendations and opinions, and of acts of the European Parliament and of the European Council intended to produce legal effects vis-à-vis third parties.

It shall for this purpose have jurisdiction in actions brought (...) on grounds of lack of competence, infringement of an essential procedural requirement, infringement of the Treaties or of any rule of law relating to their application, or misuse of powers.

This provision is considered to embody a limited jurisdiction that allows the EU Courts to review the legality of the Commission's decisions. Many scholars have argued that the review of legality does not allow the CJEU to re-examine a case on its merits. ${ }^{21}$

The limited review of legality is accompanied by an unlimited review of fines provided for in Article 261 TFEU which states that regulations adopted by the European Parliament and the Council "may give the Court of Justice of the European Union unlimited jurisdiction with regard to the penalties provided for in such regulations". Article 31 of Council Regulation 1/2003 provides that "the Court of Justice shall have unlimited jurisdiction to review decisions whereby the Commission has fixed a fine or periodic penalty payment. It may cancel, reduce or increase the fine or periodic penalty payment imposed".

It is important to observe that Article 263 TFEU places the decisions that the EU Commission adopts in competition law matters in the same class of acts with the legislative acts of the EU, the acts of the Council or the acts of

21 See Vesterdorf, Bo. "Judicial Review in EU Competition Law: Reflections on the Role of the Community Courts in the EC system of Competition Law Enforcement." Global Competition Policy 1 (2005), pp. 3-27, pp. 9 et seq.

Bailey, David. "Scope of Judicial Review under Article 81 Ec." Common Market Law Review 41 (2004), pp. 1327-136o, pp. 1330 et seq. 


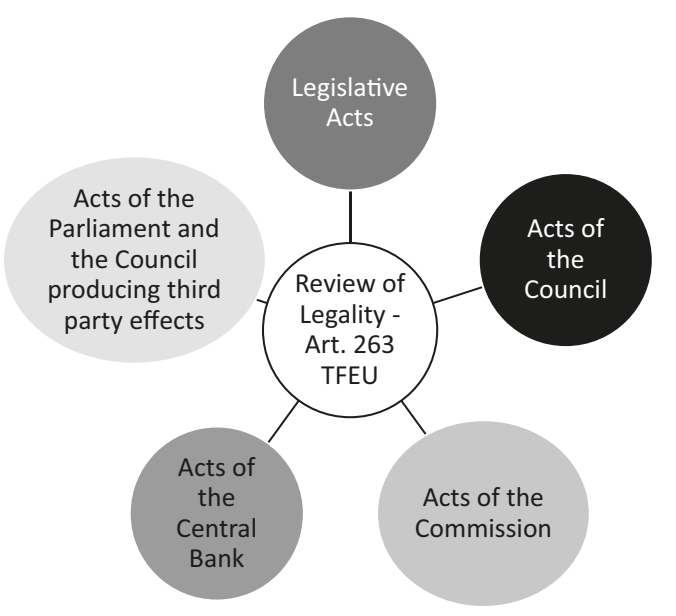

FIGURE 11 Review of legality as construed by art. 263 TFEU

the Central Bank. Figure 11 below offers a visual representation of this constitutional requirement.

The general EU judicial system of a posteriori control was directly inspired by the control of administrative bodies exercised by the French Conseil d'Etat since 1799, when Napoléon established it. ${ }^{22}$ He further noted that, even if the concept of unlimited jurisdiction is not defined in the Treaties, it appears to be derived from the French administrative law concept of recours de pleine jurisdiction. This conception of judicial jurisdiction is thought to mandate a court to "deal fully with a dispute and exercise its fullest powers. For example, a court may award damages against the administrative body or revise (as distinct from merely annulling) the administrative act in question". ${ }^{23}$ Etoa noted that an increase in the level of judicial review has occurred in relation to the administrative sanctions imposed by the French domestic agencies. ${ }^{24}$

\subsection{Limited Review of Legality - Design by Self-Interpretation}

According to the case-law of the CJEU, judicial review of the decisions of the EU institutions was arranged by the founding Treaties. In Chalkor, the ECJ

\footnotetext{
22 Derenne, op. cit., p. 74.

23 Derenne, op. cit., p. 77.

24 Etoa, Samuel. "L'évolution du contrôle du juge administratif sur la gravité des sanctions administratives." L'Actualité juridique. Droit administratif 7 (2012), Dalloz: p.358.
} 
started its analysis concerning judicial review in a competition law dispute by highlighting that, in addition to the review of legality, provided for under Article 263 TFEU, a review with unlimited jurisdiction was envisaged in regard to the penalties laid down by regulations. ${ }^{25}$ In light of this, the failure to review the whole of the contested decision of the Court's own motion does not contravene the principle of effective judicial protection. Compliance with that principle does not require that the EU Courts - which are indeed obliged to respond to the pleas in law raised and to carry out a review of both the law and the facts - should be obliged to undertake of its own motion a new and comprehensive investigation of the file.

The EU Courts have traditionally used two notions to justify maintaining limited powers of review of the EU Commission's competition law decisions: complex economic analysis and the Commission's margin of discretion.

Already in Consten and Grundig, the ECJ found that

judicial review of complex economic evaluations by the Commission (...) must take account of their nature by confining itself to an examination of the relevance of the facts and legal circumstances which the Commission deduces therefrom. This review must in the first place be carried in respect of the reasons given for the decisions which must set out the facts and considerations on which the said evaluations are based. ${ }^{26}$

Whereas initially formulated in relation to Article $101 \mathrm{TFEU}$, this reasoning was later extended to cover cases involving Article 102 TFEU and merger reviews. Thus, in Remia, the ECJ noted that, when confronted with complex economic matters, the Court must "limit its review of such an appraisal to verifying whether the relevant procedural rules have been complied with, whether the statement of the reasons for the decision is adequate, whether the facts have been accurately stated and whether there has been any manifest error of appraisal or misuse of powers". ${ }^{27}$

The EU Courts' self-restraint in cases involving complex economic/technical matters is often accompanied by its corollary principle describing the Commission's margin of discretion. Interestingly, this concept is used by the EU Courts both to justify deference to the Commission's appraisals and

\footnotetext{
25 C-386/10 P, Chalkor v Commission, ECLI:EU:C:2011:815, paragraph 53.

26 C-56/64, Consten and Grundig v Commission of the EEC, ECLI:EU:C:1966:41.

C-58/64, Grundig v Commission of the EEC, ECLI:EU:C:1965:6o. 
to deploy a comprehensive judicial review that can lead to setting aside the Commission's decision.

In Tetra Laval, the Court of Justice found that while the EU Courts

recognize that the Commission has a margin of appreciation in economic and technical matters, that does not mean that they must decline to review the Commission's interpretation of economic and technical data. The EU Courts must not only establish whether the evidence put forward is factually accurate, reliable and consistent but must also determine whether that evidence contains all the relevant data that must be taken into consideration in appraising a complex situation and whether it is capable of substantiating the conclusions drawn from it. ${ }^{28}$

This analysis has been extended by the EU Courts to other areas except competition law. ${ }^{29}$

The EU Courts justify their deferential, limited judicial review - which is employed in most competition law cases - by the need to respect the rule of law and the principle of institutional balance. In relation to the principle of rule of law, the Court established in Les Verts, in 1986, that

the European Economic Community is a Community based on the rule of law, inasmuch as neither its Member States not its institutions can avoid a review of the question whether the measures adopted by them are in conformity with the basic constitutional charter, the Treaty. (...) The Treaty established a complete system of remedies and procedures designed to permit the Court of Justice to review the legality of measures adopted by the institutions. ${ }^{30}$

This principle of rule of law is now consecrated in Article 13(2) TFEU which states that "each institution shall act within the limits of the powers conferred on it in the Treaties, and in conformity with the procedures, conditions and objectives set out in them".

The principle of institutional balance, has been established in Meroni, where the Court argued that a balance of powers was "characteristic of the

28 C-12/o3 P, Commission v Tetra Laval, ECLI:EU:C:2005:87, paragraph 39.

29 C-405/o7 P, Netherlands v Commission, ECLI:Eu:C:2008:613, paragraph 55; T-475/o7, Dow AgroScience and Others $v$ Commission, ECLI:EU:T:2011:455, paragraph 153; T-257/O7, France $v$ Commission, ECLI:EU:T:2011:444, paragraph 87. 
institutional structure of the Community".31 The principle of institutional balance is not provided as such in the TFEU, although it can be deduced from the overall structure of the Treaty.

In addition to the reasons offered by the EU Courts themselves concerning their preference for limited judicial review, scholars argue that Article 33(1) of the Treaty establishing the ECSC was the legislative precursor of the judicial self-restraint currently practiced. David Bailey showed that "as regards the evaluation of economic facts or circumstances relevant to a decision, Article 33 ECSC required the Court of Justice to ascertain only whether the Commission misused its powers or manifestly failed to observe the provisions of the Treaty or any rule of law relating to its application". ${ }^{32}$ Bailey highlights that there is no equivalent provision in the TFEU. He adds however that judicial self-restraint is well-established not only in relation to competition matters, but also in the common agricultural policy, anti-dumping duties and the medico-pharmacological sphere. ${ }^{33}$

\subsection{Unlimited Review of Fines}

The normative framework defining competition law has not suffered many changes since its inception. At the same time, the fining policy applied by the European Commission in competition law cases has changed profoundly. The Commission imposed no fines between 1962 and 1969, when the first cartel decision has been adopted. ${ }^{34}$ From that point until the 1980s, the fines imposed by the Commission remained very modest. This trend was replaced in the $198 \mathrm{os}$ by an increasingly aggressive fining policy. In Pioneer, a decision that targeted five European subsidiaries and independent distributors of the Japanese manufacturer Pioneer, the Commission imposed the first fine exceeding 10 million US Dollars. ${ }^{35}$ When Pioneer challenged this change of fining practice, the ECJ argued that

31 C-9/56, Meroniv High Authority, quoted above, paragraph 133.

32 Bailey, David. "Standard of Judicial Review under Articles 101 and 102 TFEU." The Role of the Court of Justice of the European Union in Competition Law Cases. Eds. Massimo Merola and Jacques Derennes. Bruxelles: Bruylant, 2012, pp. 103-128, p. 106.

33 Bailey (2012), op. cit., p. 106.

34 European Commission. Case IV/26.045, Quinine [1969], oJ L 192, p. 5.

35 European Commission. Case IV/29.595, Pioneer Hi-Fi Equipment [1980], oJ L 6o, p. 21. 
the fact that the Commission, in the past, imposed fines of a certain level for certain types of infringement does not mean that it is estopped from raising that level within the limits indicated in Regulation 17 if that is necessary to ensure the implementation of community competition policy. On the contrary, the proper application of competition rules requires that the Commission may at any time adjust the level of the fines to the needs of that policy. ${ }^{36}$

Forrester noted that prior to the 1980s, the "Commission's priority regarding cartels had hitherto been rather equivocal: cartels were a known and undesirable feature of economic life, but attacking a national champion was likely to be controversial, and getting good evidence was not easy". ${ }^{37}$ However, due to a change of policy in the US targeting international cartels, "the Commission wholeheartedly joined the quest against cartels, as being a primary task of a competition law enforcer". 38

The modernization program undertaken by DG COMP involved the replacement of Regulation 17/62 with Regulation 1/2003. The Fining Guidelines of 1998 have been replaced by the Fining Guidelines of 2006 and the Leniency Notice. As Tables 4 and 5 below indicate, this process of modernization has been accompanied by a concomitant increase of the fines imposed by the Commission for breaches of EU competition law. Thus, the fines imposed by the Commission between $2015^{-2020}$ represent $25 \%$ of all the fines imposed since 1990.

The more aggressive fining policy of the Commission has led to the increase in the appeals against the Commission's decisions.

The ECJ construed its own powers of review of the fines imposed in competition law cases in a broader way than the review of legality. In this sense, the ECJ has stated that the unlimited jurisdiction conferred by Article $3^{1}$ of Regulation 1/2003 authorizes the EU courts "to vary the contested measure, even without annulling it, by taking into account all of the factual circumstances, so as to amend, for example, the amount of the fine". ${ }^{39}$

36 C-10o/8o, Musique Diffusion française v Commission, quoted above, paragraph 100.

37 Forrester, Ian S. "A Challenge for Europe's Judges: The Review of Fines in Competition Cases." The Role of the Court of Justice of the European Union in Competition Law Cases. Eds. Massimo Merola and Jacques Derennes. Bruxelles: Bruylant, 2012, pp. 147-192, p. 150.

38 Forrester (2012), op. cit.

39 C-534/07 P, Prym and Prym Consumerv Commission, ECLI:E U:C:2009:505, paragraph 86. 
TABLE 4 Total of fines imposed by the Commission in EU competition law

Cases $-1990-2020^{a}$

Period

1990-1994

1995-1999

2000-2004

2005-2009

2010-2014

2015-2019

$202 \mathrm{O}^{*}$

Total
Amount in $€$

$$
\begin{array}{r}
537491550 \\
292838 \text { о०० } \\
3458421100 \\
9355867500 \\
7917218674 \\
8307828 \text { о०० } \\
278639 \text { о०० } \\
30148303824
\end{array}
$$

${ }^{*}$ Last update: 29 September 2020

a European Commission. Cartel Statistics. Available at http://ec.europa.eu/competition/cartels/ statistics/statistics.pdf accessed on 23 February 2021. Amounts as imposed by the Commission (incl. corrections following amendment decisions) and Nот corrected for changes following judgments of the Courts (General Court and European Court of Justice) and only considering cartel infringements under Article $101 \mathrm{TFEU}$ (previously Articles 81 resp. 85 and Article 82 resp. Article 86 of the Treaty), only those amounts, which concern the Article 101 TFEU, have been considered.

A few years later, in Chalkor, the Court maintained that the review of legality is supplemented by the unlimited jurisdiction which empowers the Courts, in addition to carrying out a mere review of the lawfulness of the penalty, to substitute their own appraisal for the appraisal provided by the Commission and, consequently, to cancel, reduce or increase the fine or penalty payment imposed. 40

However, despite both the Treaty-encapsulated and self-declared unlimited review of fines, the EU Courts tend to defer to the Commission's margin of appreciation when reviewing the fines. A comparison between Table 5 above describing the fines imposed by the EU Commission and Table 6 below describing the fines adjusted by the EU Courts support this view.

As Table 7 concludes, if at the beginning of the 1990s the EU Courts' review of the fines imposed by the EU Commission resulted in the fines being diminished by $35,9 \%$, starting with 1995 this number rarely went over $10 \%$. 
TABLE 5 Total of fines imposed by the Commission in EU Competition law cases $-2016-202 \mathrm{O}^{\mathrm{a}}$

Year

2016

2017

2018

2019

$2020^{*}$

Total
Amount in $€$

3726976 ооо

1945656 o००

800748 ooo

1484877000

278639000

8236896 oоo

* Last update: 29 September 2020

${ }^{a}$ European Commission. Cartel Statistics, quoted above.

Amounts as imposed by the Commission (incl. corrections following amendment decisions) and NOT corrected for changes following judgments of the Courts (General Court and European Court of Justice) and only considering cartel infringements under Article $101 \mathrm{TFEU}$ (previously Articles 81 resp. 85 and Article 82 resp. Article 86 of the Treaty), only those amounts, which concern the Article $101 \mathrm{TFEU}$, have been considered.

\subsection{Margin of Appreciation of the EU Commission and Unlimited Review of Fines}

As shown in section 16.4., the CJEU has the constitutional right to perform unlimited judicial review of the fines imposed by the Commission in competition law cases. At the same time, the analysis performed in the section above indicated that the CJEU's judicial review of fines became more deferential since the 199os. In fact, the Commission's margin of discretion is invoked by the CJEU to justify everything from the Commission's use of the Fining Guidelines, to the analysis of mitigating circumstances and impact on the market. Consistently, the Commission's margin of appreciation in fining matters is justified by the need to ensure the deterrent effect of fines. ${ }^{41}$

The present section highlights landmark cases that define the scope of the Commission's margin of discretion in fining matters.

In Archer Daniels Midland the CFI was faced with the question whether the Fining Guidelines are compatible with the principle of non-retroactivity of criminal laws. The CFI noted that that the principle of non-retroactivity of

41 C-10o/8o, Musique Diffusion française v Commission, quoted above, paragraph 108. 
TABLE 6 Total of fines imposed by the Commission, adjusted for court judgements $-1990-2020^{a}$

Period

1990-1994

1995-1999

2000-2004

2005-2009

2010-2014

2015-2019

$202 \mathrm{O}^{*}$

Total
Amount in $€$

344282 550,00

270963500,00

3157348710,00

7863307786,50

7598728479 , o०

8234322023,00

278639 o००,००

$27747592048,5^{\circ}$

* Last update: 29 September 2020

a European Commission. Cartel Statistics, quoted above.

Amounts corrected for changes (incl. corrections following amendment decisions) and judgments of the Courts (General Court and European Court of Justice) and only considering cartel infringements under Article 101 TFEU (previously Article 81 resp. Article 85 of the Treaty). Wherever prohibitions and fines concern infringements of Article 101 TFEU (previously Articles 81 resp. Article 85 and of Article 102 TFEU previously Article 82 resp. Article 86 of the Treaty), only those amounts, which concern the Article 101 TFEU infringements, have been considered.

criminal laws, enshrined in Article 7 ECHR constitutes a general principle of Community law which must be observed when fines are imposed for infringement of the competition rules. The principle of non-retroactivity of criminal laws requires that the penalties imposed correspond with those fixed at the time when the infringement was committed. At the same time, the adoption of guidelines capable of modifying the general competition policy of the Commission as regards fines may fall within the scope of the principle of non-retroactivity. ${ }^{42}$

The CFI also highlighted that by adopting and publishing the Fining Guidelines, the Commission imposes a limit on its own discretion: "it cannot depart from those rules under pain of being found, where appropriate, to be in breach of the general principles of law, such as equal treatment or the protection of legitimate expectations and legal certainty". ${ }^{3}$ The CFI concluded

\footnotetext{
42 T-59/o2, Archer Daniels Midland v Commission, ECLI:EU:T:2006:272, paragraph 42.

43 T-59/o2, Archer Daniels Midland v Commission, quoted above, paragraph 43.
} 
TABLE 7 Percentage of fine reduction by EU courts in cartel cases

\begin{tabular}{|c|c|c|c|}
\hline Period & Imposed & Adjusted & Difference \\
\hline 1990-1994 & $53749155^{\circ}$ & 34428255 ○,o० & $-35,9 \%$ \\
\hline 1995-1999 & 292838 o०० & 270963500,00 & $-7,5 \%$ \\
\hline $2000-2004$ & $345^{8} 421100$ & 3157348710,00 & $-8,7 \%$ \\
\hline $2005^{-2009}$ & 9355867500 & 7863307786,50 & $-16,0 \%$ \\
\hline $2010-2014$ & 7917218674 & 7598728 479, Оо & $-4,0 \%$ \\
\hline $2015^{-2019}$ & 8307828 о०о & 8234322 ०23,०० & $-0,9 \%$ \\
\hline $2020^{*}$ & 278639 ००० & 278639 о००,०० & $0,0 \%$ \\
\hline Total & 30148303824 & $27747592048,5^{\circ}$ & $-8,0 \%$ \\
\hline
\end{tabular}

* Last update: 29 September 2020

however that "undertakings involved in an administrative procedure in which fines may be imposed cannot acquire a legitimate expectation that the Commission will not exceed the level of fines previously imposed or the method of calculating the fines" ${ }^{44}$

In KME Germany, the Commission has fined the applicants for having organized a cartel in the air conditioning and refrigeration business. The applicants lodged an action for annulment, contesting the amount of the fine imposed on them and the fact that the Fining Guidelines used by the Commission for the calculation of the fines was a soft law instrument. ${ }^{45}$

The CFI has, first of all, highlighted that whilst the Fining Guidelines "may not be regarded as rules of law, they nevertheless form rules of practice from which the Commission may not depart in an individual case without giving reasons which are compatible with the principle of equal treatment". ${ }^{46}$ The CFI stressed that its role when reviewing the legality of the fines imposed by the Commission was twofold: (1) to assess whether the discretion exercised by the Commission is in line with the method for calculating the fines established in the Guidelines, and in the contrary (2) to verify whether the departure is justified and supported by sufficient legal reasoning. The CFI also added that "the self-limitation on the Commission's discretion arising from the adoption

\footnotetext{
44 T-59/o2, Archer Daniels Midland v Commission, quoted above, paragraph 48.

45 T-127/O4, KME Germany and Others $v$ Commission, ECLI:EU:T:2009:142.

46 T-127/O4, KME Germany and Others $v$ Commission, quoted above, paragraph 33.
} 
of the Guidelines is not incompatible with the Commission's maintaining a substantial margin of discretion". ${ }^{47}$

Furthermore, the CFI noted that the Commission's duty was not to scientifically prove the impact of a cartel on a market, but rather "to provide specific and credible evidence indicating with reasonable probability that the cartel had an impact on the market". 48

According to settled case-law, the gravity of an infringement has to be determined by reference to numerous factors, such as the particular circumstances of the case and its context; moreover, there is no binding or exhaustive list of the criteria which must be applied.$^{49}$ The criteria for assessing the gravity of an infringement may include the volume and value of the goods in respect of which the infringement was committed and the size and economic power of the undertaking and, consequently, the influence which it is able to exert on the relevant market. Thus, on the one hand, the Commission can have regard both of the total turnover of the undertaking, which gives an indication, albeit approximate and imperfect, of the size of the undertaking and of its economic power, and of the market share of the undertakings concerned on the relevant market, which gives an indication of the scale of the infringement. On the other hand, it is important not to attach on one or other of those figures an importance which is disproportionate in relation to other factors and the fixing of an appropriate fine cannot therefore be the result of a simple calculation based on total turnover. ${ }^{50}$

In addition, when determining the gravity of an infringement, particular account should be taken of the legislative background and economic context of the conduct complained of. ${ }^{51}$ Also, in order to assess the actual effect of an infringement on the market the Commission must take as a reference the competition that would exist if there was no infringement. ${ }^{52}$

47 T-127/04, KME Germany and Others $v$ Commission, quoted above, paragraphs 34-35.

48 T-241/o1, Scandinavian Airlines System v Commission, ECLI:EU:T:2005:296, paragraph 122.

49 Order in C-137/95 P, SPO and Others $v$ Commission, ECLI:EU:C:1996:13o, paragraph 54.

C-219/95 P, Ferriere Nord v Commission, ECLI:EU:C:1997:375, paragraph 33.

And T-9/99, нFв and Others $v$ Commission, ECLI:EU:T:2002:70, paragraph 443.

C-10o/8o, Musique Diffusion française $v$ Commission, quoted above, paragraphs 120 and 121.

T-77/92, Parker Pen v Commission, ECLI:E U:T:1994:85, paragraph 94.

$51 \quad \mathrm{C}-40 / 73$ (joined cases 40 to 48, 50, 54 to 56, 111, 113 and 114-73), Suiker Unie and Others $v$ Commission, ECLI:Eu:C:1975:174, paragraph 612. And C-219/95 P, Ferriere Nord $v$ Commission, quoted above, paragraph 38 .

52 C-40/73, Suiker Unie and Others v Commission, quoted above, paragraphs 619-620. T-347/ 94, Mayr-Melnhof Kartongesellschaft v Commission, ECLI:EU:T:1998:101, paragraph 235.

T-141/94, Thyssen Stahl v Commission, ECLI:EU:T:1999:48, paragraph 645. 
Where an infringement has been committed by several undertakings, the Commission must consider the relative gravity of the participation of each separate undertaking. ${ }^{53}$ The gravity of participation implies an analysis of the roles played by each undertaking in the infringement and the duration of their participation. ${ }^{54}$

In Archer Daniels Midland, the CFI has shown that the impact of a cartel on the market necessarily involves recourse to assumptions. In this respect, the Commission must in particular consider what the price of the relevant product would have been in the absence of a breach of competition law. However, when examining the causes of actual price developments, it is hazardous to speculate on the part played by each of those causes. In this situation, the Commission cannot be criticised for referring to the actual impact on the market of a cartel having an anti-competitive object, such as a price or sales quota cartel, even though it does not quantify that impact or provide any assessment in figures in this respect. Rather, the actual impact of a cartel on the market must be regarded as having been demonstrated if the Commission is able to provide specific and credible evidence indicating with reasonable probability that the cartel had an impact on the market. ${ }^{55}$ In addition, having regard to the administrative and management costs associated with the sound functioning of a complex cartel, and taking account of the risks inherent in the cartel activities, it is reasonable to assume that when undertakings persist with the infringement over a long period of time, this indicates that the cartel members made a certain profit from that cartel which, in turn suggests that the cartel had an actual impact on the relevant market. ${ }^{56}$

The Commission's discretion also extends to the seriousness of the infringement and its composing elements. ${ }^{57}$ The Commission also retains a large margin of discretion in relation to the application of aggravating and attenuating circumstances. 58

The CFI noted that the adoption of the Guidelines has not rendered irrelevant the previous case-law under which the Commission enjoys a discretion as to whether or not to take account of certain matters when setting the amount of the fines. Thus, "in the absence of any binding indication in the Guidelines

$53 \mathrm{C}-40 / 73$, Suiker Unie and Others $v$ Commission, quoted above, paragraph 623.

54 C-49/92 P, Commission v Anic Partecipazioni, ECLI:EU:C:1999:356, paragraph 15o. And T-6/ 89, Enichem Anic v Commission, ECLI:EU:T:1991:74, paragraph 264.

55 T-59/o2, Archer Daniels Midland v Commission, ECLI:EU:T:2006:272, paragraphs 16o-161.

56 T-59/o2, Archer Daniels Midland v Commission, ECLI:EU:T:2006:272, paragraph 166.

57 Joined cases T-101/05 and T-111/o5, BASF $v$ Commission, ECLI:EU:T:2007:29o, paragraph 65.

$5^{8}$ T-44/oo, Mannesmannröhren-Werke AG v Commission, ECLI:EU:T:2004:218, paragraph 307. 
regarding the mitigating circumstances that may be taken into account, it must be concluded that the Commission has retained a degree of latitude in making an overall assessment of the extent to which a reduction of fines may be made in respect of mitigating circumstances". 59

Lastly, the Commission's discretion extends to the cooperation offered by the members of a cartel during the proceedings. ${ }^{60}$ This means that only an obvious error of assessment by the Commission is capable of being censured, since the Commission enjoys a wide discretion in assessing the quality and usefulness of the cooperation provided by the undertakings that are being investigated. The quality and usefulness of the cooperation is further qualified in relation to the contributions made by other undertakings. ${ }^{61}$

\subsection{The Right to a Fair Legal Process in EU Law}

Two periods can be distinguished concerning the development of the right to a fair trial in EU law: before the adoption of the Charter on Fundamental Rights and after the adoption of the Charter.

Before the adoption of the Charter, the CJEU has recognized the existence and importance of the right to a fair trial in European law in general and in European competition law in particular. ${ }^{62}$

Thus, in Schindler Holding and Others, the applicants argued that, since the infringements of EU competition law fall within the scope of criminal law, the procedure before the Commission must satisfy the requirements of Article 6(1) ECHR. The applicants claimed that administrative authorities cannot impose penal sanctions unless there is full judicial review. They complained that an action for annulment before the Courts of the European Union was no more than an appeal before an administrative court of last resort and was limited to the pleas in law put forward by the applicants. ${ }^{63}$

The CFI initiated its argument by recalling the general principle of European Union law that everyone is entitled to a fair legal process. ${ }^{64}$ The right to a fair legal process has been reaffirmed by Article 47 of the Charter

$59 \mathrm{~T}-127 / 04$, KME Germany and Others $v$ Commission, quoted above, paragraph 115.

$60 \quad$ C-328/o5, SGL Carbon AG v Commission, ECLI:EU:C:2007:277, paragraph 88.

$61 \mathrm{~T}-127 / 04$, KME Germany and Others $v$ Commission, quoted above, paragraph 141.

$62 \mathrm{C}-185 / 95$, Baustahlgewebe GmbH $v$ Commission of the European Communities, ECLI:EU:C:1998:608, paragraph 21.

63 T-138/o7, Schindler Holding and Others $v$ Commission, ECLI:EU:T:201:362, paragraph 49.

64 C-411/o4 P, Salzgitter Mannesmann v Commission, ECLI:EU:C:2007:54, paragraph 40. 
of Fundamental Rights of the European Union and is inspired by the fundamental rights which form an integral part of the general principles of EU law which the EU Courts enforce, drawing inspiration from the constitutional principles common to the Member States and from the guidelines supplied, in particular, by the ECtHR. ${ }^{65}$

The CFI explained, however, that the Commission's decisions imposing fines for the infringement of competition law are not criminal in nature and that, furthermore, the Commission is not a 'tribunal' for the purpose of Article 6(1) ECHR. However, the CFI found that the review of Commission decisions which the Courts of the Union carry out ensures that the requirements of a fair process, as enshrined in Article 6(1) ECHR are satisfied because the applicants may call upon it to undertake an "exhaustive review of both the substantive findings of fact and the Commission's legal appraisal of those facts".66 Furthermore, in so far as concerns the fines, the EU Courts have unlimited jurisdiction.

On appeal, the applicants complained that the Commission's procedure infringes the principle of the separation of powers and does not comply with the principles of the rule of law that are applicable to criminal procedures under Article 6(1) ECHR. They argued that the case-law to which the CFI referred to in its judgment was obsolete due to the entry into force of the Treaty of Lisbon and the direct applicability of the ECHR. ${ }^{67}$

The CJEU noted first of all that the contested decision was adopted before the entry into force of the Lisbon Treaty. Second, whilst, as Article 6(3) TEU confirms that fundamental rights recognised by the ECHR constitute general principles of the European Union's law and whilst Article 52(3) of the Charter requires rights contained in the Charter which correspond to rights guaranteed by the ECHR to be given the same meaning and scope as those laid down by the ECHR, the latter does not constitute, as long as the European Union has not acceded to it, a legal instrument which has been formally incorporated into European Union law. ${ }^{68}$ Despite the ECtHR's judgment in Menarini Diagnostics, the fact that decisions imposing fines in competition matters are adopted by the Commission is not in itself contrary to Article 6(1) ECHR. On contrary, the

65 T-138/o7, Schindler Holding and Others $v$ Commission, quoted above, paragraph 51.

$66 \mathrm{~T}-138 / 07$, Schindler Holding and Others $v$ Commission, quoted above, paragraph 56.

67 C-501/11 P, Schindler Holding and Others v Commission, ECLI:Eu:C:2013:522, paragraphs 24-29.

68 C-571/10, Kamberaj, ECLI:EU:C:2012:233, paragraph 62. And C-617/10, Åkerberg Fransson, ECLI:EU:C:2013:105, paragraph 44. 


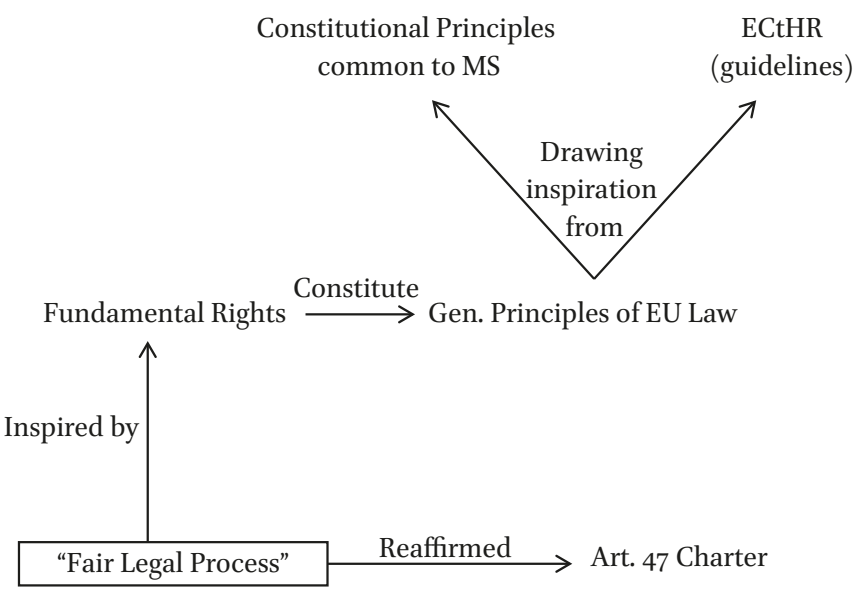

FIGURE 12 Design of the "Fair Legal Process" in the case-law of the EU courts

CJEU argued that the review performed by the European judicature was compatible with the requirements of Article 6(1) ECHR. ${ }^{69}$

Figure 12 below offers a visual representation of the design of the notion "fair legal process" as summarised by the EU Courts in Schindler Holding and Others and applied consistently in the case-law. This visual representation suggests that the notion of "fair legal process" is a fundamental right, part of the general principles of EU law, which is inspired by the ECtHR's case-law and the constitutional principles common to the member states. The right to a fair legal process is reaffirmed in Article 47 of the Charter.

The CJEU interpreted the right to a fair legal process to "comprise the right to a tribunal that is independent of the executive power in particular". ${ }^{70}$ The CJEU also found that the right to a fair legal process comprised "the right to a legal process within a reasonable time". ${ }^{71}$ The CJEU have also had the opportunity to apply the right to a fair legal process in relation to national insolvency proceedings. In Eurofood, the ECJ noted that the right to be notified of procedural documents and, more generally, the right to be heard, "occupy an eminent position in the organisation and conduct of a fair legal process. In the context of insolvency proceedings, the right of creditors or their representatives to participate in accordance with the equality of arms principle is of particular importance". ${ }^{72}$

69 C-501/11 P, Schindler Holding and Others $v$ Commission, quoted above, paragraphs 30-39.

70 C- 174/98 P (joined with C-189/98 P), Kingdom of the Netherlands and Gerard van der Wal $v$ Commission of the European Communities, ECLI:EU:C:20oo:1, paragraph 17.

$71 \mathrm{C}-185 / 95$, Baustahlgewebe GmbH v Commission of the European Communities, quoted above, paragraph 21.

72 C-341/04, Eurofood IFSc Ltd., ECLI:EU:C:2006:281, paragraph 66. 
The ECJ also added that although

the specific detailed rules concerning the right to be heard may vary according to the urgency for a ruling to be given, any restriction on the exercise of that right must be duly justified and surrounded by procedural guarantees ensuring that persons concerned by such proceedings actually have the opportunity to challenge the measures adopted in urgency. ${ }^{73}$

Moreover, the right to a fair trial plays an important role in the practice of EU institutions. First, it is important to highlight that since, the entry into force of the Charter, most letters and petitions received by the EU Commission in relation to the Charter concern access to justice. Figure 13 below indicates that $36 \%$ of the letters received by the EU Commission in 2010 concerned questions about access to justice, including questions about the right to a fair trial and rights of defence.

The CJEU has also increasingly referred to the Charter in its decisions. From 2011 to 2014, the number of decisions quoting the Charter in their reasoning increased from 43 to 210 . Since 2014, that number stayed at around 200. ${ }^{74}$ As Figure 14 below shows, the Charter is most often invoked by the CJEU in relation to questions concerning access to justice.

Lastly, the right to an effective remedy and to a fair trial is the most referred to provision of the Charter by the CJEU. Figure 15 below describes the statistics for 2017 as an example.

The CJEU has invoked or relied on Article 47 of the Charter in almost 800 cases since $2010 .{ }^{75}$ As the cases below indicate, the CJEU has embraced a wide interpretation of the right to effective judicial review in many cases. First, in cases concerning review of restrictive measures such as freezing of assets, the CJEU highlighted that, in light of fundamental rights forming an integral part of the EU legal order, they must ensure the full review of the lawfulness of all the acts of the EU.76 In a recent case, the CJEU highlighted the following:

73 C-341/O4, Eurofood IFsc Ltd., quoted above, paragraph 66.

74 European Commission. 2017 Report on the Application of the EU Charter of Fundamental Rights, p. 25. Available at https://ec.europa.eu/info/aid-development-cooperationfundamental-rights/your-rights-eu/eu-charter-fundamental-rights/application-charter/ annual-reports-application-charter_en accessed on 23 February 2021.

75 This information has been collected from InfoCuria, using the search function. Available at: http://curia.europa.eu, accessed on 23 February 2021.

76 Joined Cases C-584/10 P, C-593/10 P and C-595/10 P, European Commission and Others $v$ Yassin Abdullah Kadi, ECLI:EU:C:2013:518, paragraph 97. 


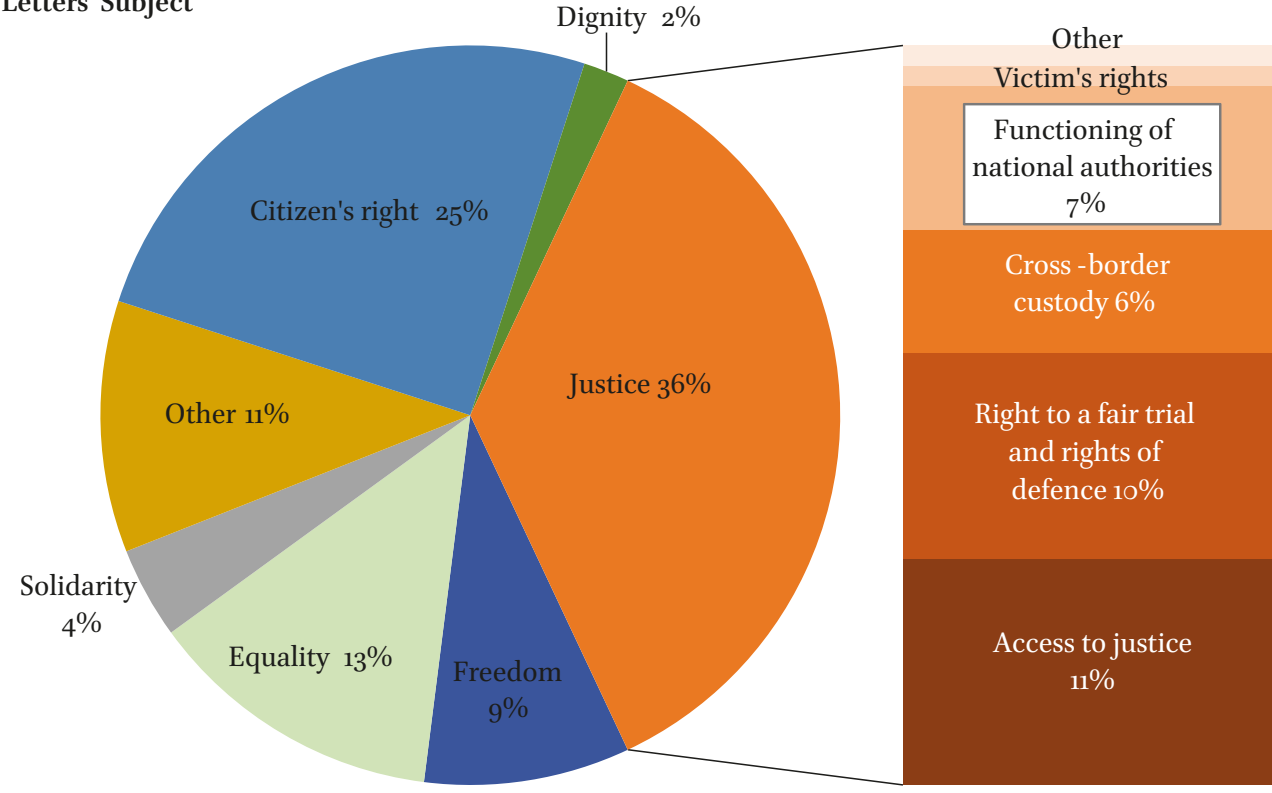

FIGURE 13 Letters received by the EU Commission in relation to the Charter divided by subject SOURCE: EUROPEAN COMMISSION. 2010 REPORT ON THE APPLICATION OF THE EU CHARTER OF FUNDAMENTAL RIGHTS, P. 76. AVAILABLE AT: HTTPS://OP.EUROPA.EU/ EN/PUBLICATION-DETAIL/-/PUBLICATION/3883477D-A821-40DB-B01E-890439FA8942/ LANGUAGE-EN ACCESSED ON 23 FEBRUARY 2021.

The effectiveness of the judicial review guaranteed by Article 47 of the Charter requires (...) that, as part of the review of the lawfulness of the grounds which are the basis of the decision to include or to maintain a person's name on the lists of persons subject to restrictive measures, the Courts of the European Union are to ensure that that decision, which affects that person individually, is taken on a sufficiently solid factual basis. That entails a verification of the factual allegations in the summary of reasons underpinning that decision, with the consequence that judicial review cannot be restricted to an assessment of the cogency in the abstract of the reasons relied on, but must concern whether those reasons, or, at the very least, one of those reasons, deemed sufficient in itself to support that decision, are substantiated. ${ }^{7}$

77 C-530/17, Mykola Yanovych Azarovv Council, ECLI:EU:C:2018:1031, paragraph 22. 


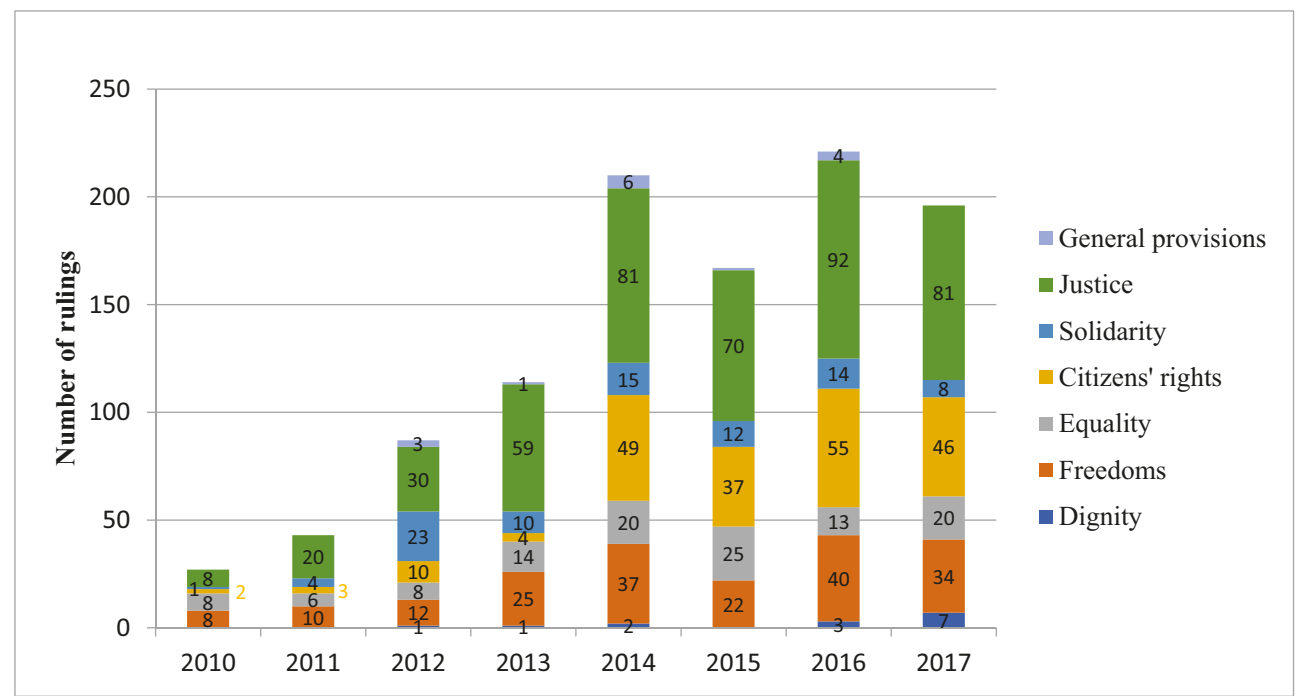

FIGURE 14 Overview of CJEU case-law which quotes the Charter or mentions it in its reasoning SOURCE: EUROPEAN COMMISSION. 2017 REPORT ON THE APPLICATION OF THE EU CHARTER OF FUNDAMENTAL RIGHTS, QUOTED ABOVE, P. 25.

\section{Percentage of references to particular articles of the Charter in decisions of the Court of Justice of the European Union 2017}

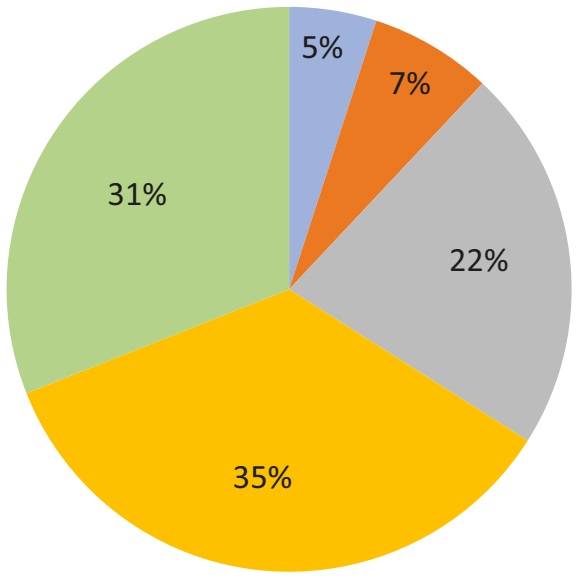

Art 17 right to property

Art 21 non-discrimination

Art 41 right to good administration

Art 47 right to an effective remedy and to a fair trial

Other rights

FIGURE 15 Most quoted Charter provisions in the case-law of the CJEU in 2017 SOURCE: EUROPEAN COMMISSION. 2017 REPORT ON THE APPLICATION OF THE EU CHARTER OF FUNDAMENTAL RIGHTS, QUOTED ABOVE, P. 27. 
Second, in relation to the right to an effective remedy concerning EU rules on asylum, the CJEU found that Article 47 of the Charter, read together with Articles 18 and 19(2) of the Charter, required that applicants for international protection should be able to enforce their rights effectively before a judicial authority. ${ }^{78}$

Despite these developments, the entry into force of the Charter has not affected the limited approach to judicial review preferred by the CJEU in competition law cases. On the one hand, the EU courts ceased to refer to Article 6( 7$)$ $E C H R$, arguing that "Article 47 of the Charter implements in European Union law the protection afforded by Article 6(1) of the ECHR. It is necessary, therefore, to refer only to Article $47{ }^{\prime \prime}{ }^{79}$

On the other hand, the CJEU has recently highlighted in relation to Article 47 of the Charter that the system of judicial review of Commission decisions relating to proceedings under Articles 101 and $102 \mathrm{TFEU}$ "consists in a review of the legality of the acts of the institutions for which provision is made in Article 263 TFEU, which may be supplemented, pursuant to Article $261 \mathrm{TFEU}$ and at the request of applicants, by the General Court's exercise of unlimited jurisdiction with regard to the penalties imposed in that regard by the Commission". ${ }^{80}$

The case-law described in this chapter exemplifies what Conway qualified as a lack of a unifying principle of interpretation. He has shown that "the ECJ has never set out a systematic scheme of interpretative principles". ${ }^{81}$ Instead, the ECJ has a "long-standing practice (...) to downplay the significance of legislative and Treaty texts, in favour of a pro-integration innovation and extension of existing legal rules related, at a high level of generality, to the purpose of integration". ${ }^{82}$ This conclusion finds evidence easily in the area of effective judicial protection in the EU.

Three periods of interpretation can be deduced from the case-law described above in relation to the right to a fair trial in EU law. First, ignoring the wording of the Treaties, the CJEU established that the right to effective judicial protection was a general principle of EU law derived from the constitutional traditions common to the Member States and from Articles 6 and 13 ECHR. Second, the CJEU established the right to a fair legal process derived from the constitutional traditions common to the Member States and the guidelines offered

\footnotetext{
78 C-175/17, Xv Belastingdienst/Toeslagen, ECLI:Eu:C:2018:776.

79 C-386/10 P, Chalkorv Commission, paragraph 51.

8o C-99/17, Infineon Technologies aG v Commission, ECLI:Eu:C:2018:773, paragraph 47.

81 Conway, Gerard. The Limits of Legal Reasoning and the European Court of Justice. Cambridge: Cambridge University Press, 2012, p. 147.

82

Conway, op. cit., p. 170.
} 
by the ECtHR. Lastly, following the entry into force of the Charter, the CJEU has abandoned Article 6(1) ECHR and the guidance offered by the ECtHR as a benchmark for the interpretation of the effective judicial protection and of the right to a fair legal process.

Before the entry into force of the Charter, the CJEU has chosen to define the principle of judicial protection and the right to a fair trial in the EU having Article 6(1) ECHR as a benchmark. In other words, the CJEU has opted for a high level of generality in the interpretation of these concepts. This choice should have led to a progressive widening of the concept of fair legal process because its benchmark - Article 6(1) ECHR - has enlarged its scope as well. As shown above, in EU competition law proceedings this has not been the case and the CJEU chose a minimal approach to due process in this area.

Following the entry into force of the Charter, the CJEU has narrowed the level of generality applied in relation to the interpretation of the right to a fair trial by abandoning the previous, Article 6(1) ECHR benchmark.

I have shown in this chapter that the CJEU has not only established general principles of EU law inexistent in the Treaties, but has used a high level of generality for their definition. The CJEU appears to have followed the strategy employed by the ECtHR concerning rights creation and rights interpretation. They have defined effective judicial protection and fair trial using Article 6(1) ECHR as a benchmark in order to capture disputes within the net of its jurisdiction which would otherwise not be justiciable. At the same time, the case-law on competition law indicates that CJEU the has maintained a narrow interpretation of effective judicial protection and fair trial. This narrow interpretation of effective judicial protection and fair trial focuses on substantive fair trial issues such as access to documents or reasoning of decisions. At the same time, this interpretation ignores the structural issues related to effective judicial protection and fair trial, such as the independence of the EU Commission as an adjudicator and deferential judicial review. 